\title{
Path Dependence and the Authoritarian Regime in Traditional Chinese Culture: a Historical Institutionalism Framework of Analysis
}

\author{
Liu Xuanhui \\ Dep. Political Science, University of Antwerp \\ Antwerp, 2000, Belgium \\ E-mail: Xuanhui.Liu@ua.ac.be
}

Received: December 18, 2012 Accepted: February 15, 2013 DOI: 10.5296/jpag.v3i1.2507

\begin{abstract}
The democratic transition in China seems to be more difficult than the European countries. Especially after three decades economic reform, the debates about the future direction of democratization become more heated than ever. This article analyzes the influences of traditional culture on democratization from historical institutionalism perspective. The article gives out four dimensions framework to explain the path dependence of traditional authoritarian culture. These four dimensions include: the bureaucratic system, Confucian theory, the imperial examination system, and rewards and punishing measures. It explains why the authoritarian culture could be accepted by the public and how it influences peoples' behavior.
\end{abstract}

Keywords: Path dependence; Authoritarian regime; China; Democracy 


\section{Introduction}

Democracy has been a controversial issue in political science. Along with China is emerging as an important power in the world economy and political stage, its democratic transition gets more attentions by the scholars. Some scholars are optimistic and claim that economic development would improve democratization in China (Held et al, 1999). Some scholars hold neutral position on this topic. They are lost in the controversial facts that pro and against democratization. Their conclusion is that "it depends" (Lewis and Xue, 2003). Another aspect holds pessimistic opinion about democratization in China. They think that economic development has delayed democracy in China (Gallagher, 2002). Some Chinese scholars claim that democratic issues must be related with the specific economic and cultural context (Luo, 2007). These disputes reflect the different opinions on democracy. However, they could not answer why some countries are easy to transfer into democratic country while other counties not. Friedman (1999, p. 346) criticizes Nathan (one of America's most distinguished senior analysts of Chinese politics) that he could not show how the Confucian particulars foster obstacles to democracy larger than other thoughts. Some political scientists believe that transition of democracy is related with the political structure. For example, Huntington claims that the complex political structure would be more difficult to be abolished (Huntington, 1988). What is the complex political structure? Where does it come from? How could it influence the democratization of the political regime? These questions would be vital to answer the question why some country are easy to transfer into democratic regime while the others not.

Some Chinese scholars have analyzed the reasons of why it is difficult to implement democratic politics in China. For example, Liang Shuming, a guru in comparative study on the Western and Chinese culture, says that one of the most distinguished characteristic of Chinese traditional culture is no democracy (Liang, 2006). The basic elements of democracy, such as, the Western rational sprit is absent in Chinese culture; meanwhile, the ethic replaced the function of religion is another characteristic of the Chinese culture (ibid). He claims that China is a country ruled by man not by rationality and law. Ning ke (2009) asserts that the feudal land property institutions play a vital role in the process of strengthening the authoritarian regime. The feudal landlords did not have absolute property rights as their peers in the Western Europe's manor system. They did not have enough power to against the emperor. He states that the economic reason is a major precondition of the authoritarian ruling. We could also find explanations from other aspects. But these discussions could not give us a holistic view. The basic logic of these articles is that democracy is consisted in different elements of the social system. Sometimes, it would cause the effects like the blind man touching the elephant. Different people may get different conclusions.

From the methodological perspective, we find an important weakness of previous researches on this issue. They use the modern criteria of democracy to evaluate the historical affairs. I hold a skeptical attitude to this method. In certain historical period, the authoritarian regimes have some advantages in social and economic development, for example, improving the productivity, keeping the society stable, uniting people to defend nature disaster, building the great project, and so on. In this sense, the authoritarian regimes are indeed useful to social 
development of that time. Therefore, we have to rethink our analyzing method.

In this article, I attempt to answer this question from historical institutionalism perspective. The article is structured as follows. The first part introduces why the historical institutionalism is employed as an analyzing method; the second part analyzes the origin of authoritarian institution; the main body of this paper focuses on how the authoritarian institutions are strengthened, and how the institutions are permeated into the Chinese traditional culture; the final part is discussion and conclusion.

\section{Historical Institutionalism as an Analyzing Method}

Historical institutionalism defines institutions as the formal or informal procedures, routines, norms and conventions embedded in the organizational structure of the policy or political economy (Hall, 1996). When we put the transition of democracy into the long history of a nation, historical institutionalism might be a proper method to analyze this issue. The reasons can be explained from three aspects.

First, it offers us an integrative approach to analyze this issue. The traditional methods focus on how the democracy was constructed and influenced. It always falls into the myriad influencing factors and could not give the readers a clear impression, because democracy is a complex outcome of the socioeconomic context of history. We would be lost in the jungle if we could not grasp the clue. Now we take authoritarianism as an institution directly. Through analyzing the questions, such as, how such an institution comes up and how it was strengthened or transferred, we would put this issue under an organized framework. It will help us to analyze the process of how such an institution changed from a simple structure into a complex structure.

Second, the historical institutionalism is a meso-level theory (Thelen and Steinmo,1992). The institutionalists have constructed important analytic bridges: between state-centered and society-centered analysis by looking at the institutional arrangements that structure relations between the two and between the grand theory that highlight broad cross-national regularities and narrower accounts of particular national cases, by focusing on intermediate-level variables that illuminate sources of variation on a common theme (ibid, p10). Through the institutional analysis, we could know how the institutions shape and constrain the political strategies and how the political strategies and political conflicts and choice strengthened the institutions as a synthetical outcome.

Third, institutional analysis keeps a neutral position from the methodological perspective. It would help us to avoid the value judgment in this issue. As I have pointed the methodological shortcoming on analyzing the historical issues, we could not use the modern value judgment to analyze the history. The institutional analysis will avoid this pitfall.

Historical institutionalism combines the static analysis and dynamic analysis together. The static analysis emphasizes the representations of authoritarian regimes, its functions and meanings, especially the origin of dictatorship. The dynamic analysis focuses on the transition of the authoritarian regime, for example, the political changes and power conflicts and their interaction with institutions. 
Some propositions from historical institutionalism also give us insights on analyzing this issue. For example, it claims institution is an organized pattern of roles, often enforced with positive and negative sanctions; meanwhile, it is the patterned habits of thought learned by individuals performing those roles (Dugger, 1980). These insights would help us understanding the socialization procedure of the authoritarian regime and how it has been permeated into the traditional culture. Furthermore, the historical institutionalism emphasizes the power asymmetries associated with the operation and development of institutions; another characteristic of institutional analysis is that they emphasize path dependence and unintended consequences (Hall, 1996). These points are the foundation for us to analyze the authoritarianism and its transition in China.

\section{The Origins of Dictatorship in China}

Choosing the starting point is important to historical institutionalism. According to the path dependence theory, the starting point would influence the future institutional development. Different starting point may result in different conclusion in the research. Moore describes the origins of dictatorship in his book Social Origins of Dictatorship and Democracy (Moore, 1966). But his research focuses on relationship between revolution and political choice. In fact, he does not give a direct explanation about the origins of dictatorship and democracy in China. To some extents, he takes dictatorship as a given premise, especially in the verbosity chapter about China. I think, we have to dip into the institutional settings if we want to make clear the origins of authoritarian institution.

When we look back the history of China, Qin Dynasty (221BC-207BC) is a pivotal stage we need to pay more attentions. Why do we start to analyze from Qin Dynasty? At least two reasons lie here. First, most of the historians agree with that Qin Dynasty is the first united feudal society in Chinese history, it is the starting point of feudal society in China; Second, Qin Dynasty made many institutional innovations in the history, which were marked as a starting point of the feudal society. These institutions influence the whole history of feudal society. The famous reformist, Tan Sitong, said that the two-thousand years political history of China could be concluded into one sentence - it was the politics of Qin Dynasty (Tan, 1994).

In theory, it is difficult to give a clear demarcation of the starting point. Some Chinese scholars (Wang, 1984) claim that the authoritarianism was derived from the Zhou Dynasty (1046-256BC). Of course, no institutions could be invented without the influence of the former institutions. But I think the authoritarian regime is a set of institutions. The single institutional reform or characteristic of dictatorship could not be seen as the starting point of the authoritarian regime. Only in Qin Dynasty, we can find the systematic reform in institutions. The framework of the authoritarianism was set up. That is another reason to choose Qin Dynasty as the starting point.

Some initiative reforms have been done in Qin Dynasty, which have influenced the whole feudal history of China. In political fields, the centralized government replaced the system of enfeoffment. The emperor charged all the rights. In central government, Qin established the Three Lords and Nine Ministers administrative institution (三公九卿制) (it seems like the 
separation of executive, legislative and judicial rights in modern politics superficially, but they have differences in essence). The Three Lords are, the Chancellor (丞相), the Imperial Secretary (御史大夫) and the Grand Commandant (太尉). Three Lords controlled each other and they were all responsible for the emperor. The Grand Commandant, who is in charge of the military, is an ostensible position (Zhu, 1988). The real military power was still in the hand of the emperor. That is one principle in the feudal society that the military rights must be controlled by the emperor. The Nine Ministers were responsible for the Chancellor. The Three Lords and Nine Ministers were appointed by the emperor and could not be inherited by their descendants. A new local government system Jun-Xian-Zhi (Province-County system) was established. Qin set up the hierarchical administrative system, which is a three-level management (central government-province-county). The local administrators were appointed by the central government. The nobles had no rights to appoint the local governors. Through the political reforms, the nobles' rights were weakened. The emperor has seized the top position of the power pyramid and the absolute rights.

In economic fields, based on the strong military rights, the old well-field system (井田制) was abolished. The land of the nobles was confiscated and allocated again. The new lands were allowed to sale and transfer. The nobles or the feudal land lords may own the land, but they don't have the privilege. The relationship between peasants and the feudal lords was contractual relationship. These points are different from the feudal land property rights in Western Europe. To some extends, the peasants in China are independent from the feudal landlords. The feudal landlord has a weak economic control over the peasants. These measures has weakened the power of local governments and strengthened the emperors' control.

In the military sector, the Qin Dynasty established the standing army institutions. There were nearly one million standing soldiers in Qin; Qin innovated the Agriculture-War institutions (农战制度), which means, in the spare time, the army would engage in agricultural activities, in the war time, they would be put into the battles. At the same time, Emperor Qin strengthened the merit system. There was an award regulation for the people who serve in the army. Another point is that the local governments had no rights to control the army, which was an important measure to strengthen the emperor's power.

In the cultural field, Qin Dynasty set up the unified policy to strengthen cultural control over the whole country. To restrict the thoughts, Qin established law to forbid the knowledge spreading in the country. The private school was forbidden, the classic literatures were burned, especially in 212AD, 464 scholars were buried because of discussing the politics. Meanwhile, Emperor Qin standardized the currency, metric system and Chinese script (汉字). Such a standardization process, like the Roman road system or Bismarck's reform in Germany occurred 2000 years later, had a profound meaning for China to keeping as a united multinational country. But from another perspective, these measures unified the thoughts and strengthened the control in cultural sector. Culture and education served as ruling apparatus of the authoritarian country.

Besides these measures, Emperor Qin established severe law to punish the rebellions and 
dissidents. For example, Lianzuo (连坐), a law to punish the one who is guilty with his clan together, is always cited as cruel law in Qin Dynasty.

Through these measures, a comprehensive system for controlling over the state and its people was established. Although Qin's ruling lasted only 15 years, the initiative reforms in institutions have profound meaning to its successors. It has influenced the feudal history of China for 2000 years. In the terminology of institutionalism, that is path dependence. Qin Dynasty established an authoritarian model in the early stage of Chinese history.

\section{How Authoritarian Institutions Are Strengthened}

Pierson uses the path dependence and increasing returns to describe the reasons why once the institutions were set up, it would be difficult to change (Pierson, 2000). But the path dependence and increasing returns could not happen automatically. The democratization is a collective activity in nature. The result of institutional development depends on the efforts and capability of the dominate group. In order to make clear the history of authoritarianism in China, we need to know how the authoritarian regimes are strengthened. I summarize the measures to strengthen authoritarian regime into four aspects: the bureaucracy system, the Confucian theory, the imperial examination system, and the rewards and punishment measures respectively. These four aspects are derived from the authoritarian pattern set up by Qin. There are also intrinsic connections and interaction between these aspects. They form a composite force to strengthen the authoritarian regime.

\subsection{Modifying the bureaucratic system}

The government is the core of a political system. We can distinguish the changes and power distribution though the government structure. In historical institutionalism perspective, structure is the synonymous word as institution (Hall, 1996). Therefore, the political structure of the regime should be paid more attentions. Especially, the structure of the bureaucratic system could show the changes and distribution of power clearly. That is one reason that I put it in the first place.

The governmental system in Qin dynasty established a model for the future. The emperor got absolute control over the whole country. But Qin dynasty had existed for only 15 years. According to the assumption of institutionalism, the newly established institutions would be changed easily, the more difficult the later. As we know, in early stage of Han Dynasty, the Rebellion of the Seven States (154BC) almost overturned the central government. That was the first time of the struggle between the nobles and the emperor. The war was ended with the failure of the Seven States. The emperor strengthened his power again. The nobles' rights were reduced. Followed with a serial of reforms, the comprehensive authoritarian regimes were established in Western Han Dynasty.

As Creel observed, in Han dynasty (BC206-220AD), shortly after Qin dynasty, they have already fully developed Weber's features of "modern bureaucracy" (Creel, 1964;Hood, 1998).

As early as the Han dynasty, the Chinese bureaucracy...depended for his professional 
advancement upon his evaluation by other officials on the basis of relatively objective criteria: grades obtained in examinations, experiences and seniority, voluminous records of his performance in office, and merit ratings. The central government kept itself informed of local conditions by means of various systems of inspection and a voluminous flow of reports and statistics. It estimated its income and budgeted its expenditures. Like some governments of our own day, it sought to control economic activity... (cited from Hood, 1998)

In fact, Hood forgot to analyze the foundation of so called modern bureaucracy in Han dynasty. The powerful emperor strengthened his control over the whole country by the military forces. The land lords of local region were weakened. The nobles and local land lords did not have power to against the emperor. The power asymmetry paved the way for the reforms. As Creel and Hood observed, the modern bureaucracy was established in China two thousand years ago. Such a bureaucracy system has a feature of stability, which would be helpful for the emperor to control the local officials through the hierarchical ruling. This is one important difference compared with the manor system in Western Europe, where the lords of manor had the relative autonomous power even in early stage of industrial revolution and the emperors' power were limited.

In Tang Dynasty, the highest point of feudal civilization in ancient China, a more complex bureaucracy system was developed. That is Three Departments and Six Ministries System (三 省六部制). It replaced the Three Lords and Nine Ministers system that was instituted in Qin Dynasty (221-206 BC). The three departments were the Secretariat (中书省), the Chancellery (门下省, also translated as "Edict Examination Bureau"), and the Department of State Affairs (尚书省), while the six ministries referred to the Ministry for Personnel (吏部), Revenue (户 部), Rites (礼部), War (兵部), Justice (刑部) and Works (工部) . The six ministries are charged by the department of state affairs. The figure below shows the hierarchical structure.

Figure 1. Structure of Central Government in Tang Dynasty

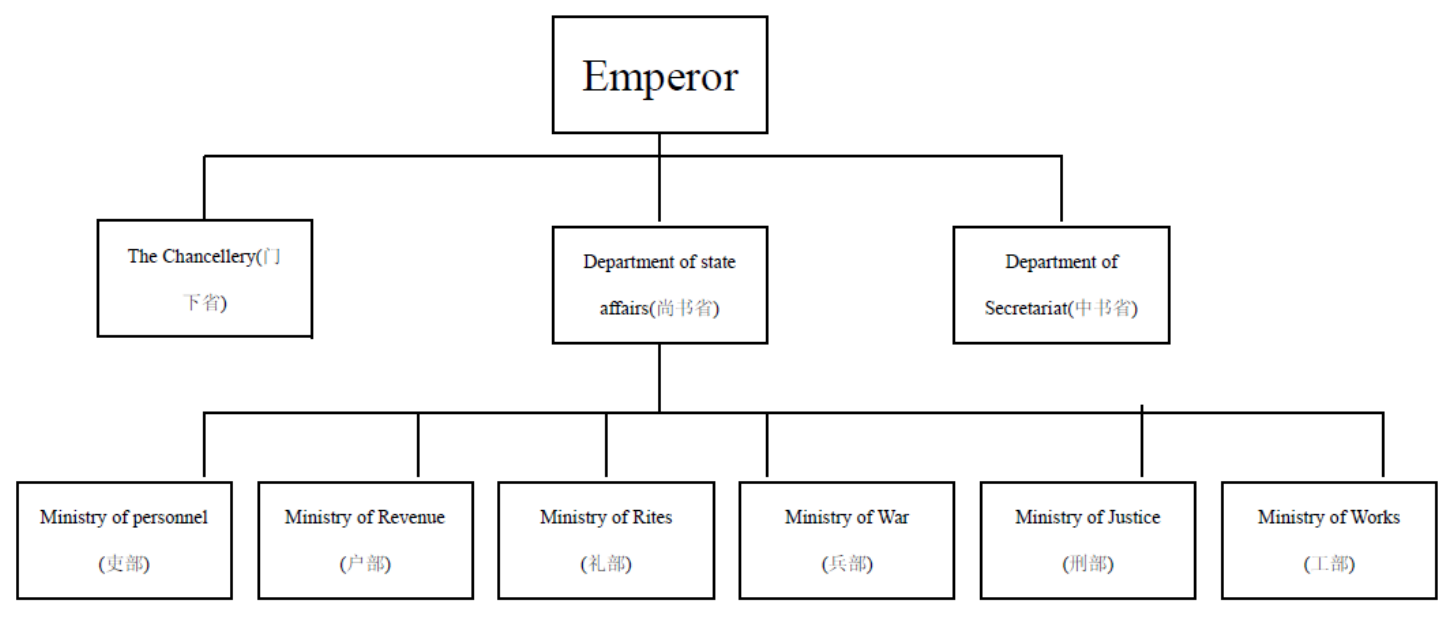

In Ming (1368-1644) and Qing Dynasty (1644-1911), the feudal centralization regime got further development. The position of prime minister was aborted from the government structure. Six ministries are responsible for the emperor directly. 
We can find a clear trend from the reforms of the bureaucracy system: the more development of economy the more centralized the bureaucratic system. It seems to contradict with the common law of democratization. According to the basic trend of democracy, democracy would develop with the civilization and economic development. How could this happen in China?

From the perspective of institutionalism, the unintended consequences would lead the change in institutional development. But why there is no further development to the democratic direction as the Western Europe. We saw some disunion periods in the feudal history, for example, the Five Dynasties and Ten States (907-979). Why such a disunion situation always could not last long, these are the questions we need to think. The power asymmetry is one reason. The further reasons could be found from the cultural perspective.

\subsection{The Confucian Theory}

Aristotle once said, "The best policy which would be used by the democratic regime or the authoritarian regime, is not the policy that could expand the ruler's unlimited power, but the policy that could ensure their authority" (cited from Huntington, 1988). The Confucian theory plays this function to strengthen the authoritarian regime.

Confucian theory is a collective wisdom. It was originally put forward by Confucius(551BC-479BC) in Spring and Autumn Period (770BC-476BC). It was developed by Mencius, Xun Zi, Zhu Xi, Wang Yangming et al. Almost in every dynasty, there were some gurus explained and developed the Confucian theory under the new context. The Confucian theory was recorded by his disciples. The classic Confucian theory contains in Four Books and Five Classics, which are the contents of the imperial examination.

Why could Confucian theory be accepted by the feudal rulers as official ideology? The answer is that it meets the needs of the authoritarian regime. It could be divided into two aspects. Firstly, it advocates the legitimacy of emperor's ruling over the country. In Confucian theory, the emperor is the son of Heaven (God). He was send by the Heaven to rule the ordinary people. The Emperor is perfect in virtue and highest in position. Therefore, his supremacy dominance is unshakable. The obedience to the emperor is the loyalty to the state. It has similarity as the Christian theology to combine the divine rights of the emperor with religion.

Second, the most important point is that the Confucian theory has established comprehensive behavior and moral principles for the secular society. According to Confucian theory, the harmonious society should have an order. That is the three cardinal guides (ruler guides subject, father guides son and husband guides wife) and the five constant virtues (benevolence, righteousness, propriety, wisdom and fidelity, in Chinese (三纲五常) as specified in the feudal ethical code. These theories construct the social order and ethical norms for the whole society. To the rulers, it supports the legitimacy of authoritarian hierarchy systems. The subordinates should obey the order of rulers. In the family, there is also a hierarchy system, father is the head of the family and husband is the head of his wife. All the people in the society should obey the five constant virtues. A harmonious society 
should run under such circumstance. Hence, it sets up a hierarchy system centered on the emperor.

I think the starting point of Confucius maybe right. He tried to curb the chaos and virtue degradation of the War States Period (475BC-221BC). However, his thoughts were used by the rulers to serve for the authoritarianism later. In the country, the emperor's supremacy dominance position could not be touched and shaken. The relationship between the emperor and subordinates was strengthened by ritual and hierarchy system. One important thing is that obeying and respecting such hierarchy system is also one virtue of the ordinary people. In the family, it almost copies the model of the feudal monarchy. Father determines everything in the family, including his wife's freedom of speech. The son and daughter have no freedom to express their own idea but to obey father's order. Meanwhile, the family education influences offspring. Such authoritarian thoughts has been lasted generation after generation. That is a socialization process. The hierarchy system exists not only in the government, but also in the family and the community and every corner of the society, permeated in every sector of people's life. Cooperated with the Confucian virtue ethics, a feudal authoritarian social order was constructed. In the local level, it could even run well without the governments' interfering. B. Russell once said that China was a cultural entity but not a country. Robert E. Park also had same conclusion (cited from Liang, 2006). What they mean is that the Confucian culture is permeated into the secular life. In the village, the hierarchy value, the ritual system and the ethics, which were constructed by the Confucian theory, will play its ruling functions. Therefore, they do not need a government. And in the whole country, the influences of Confucian theory are the same. Based on the Confucian theory, the comprehensive hierarchical value about social life and ethics was constructed. It influences everyone's thoughts. Generation after generation, such obedience and loyalty to the hierarchical authoritarian control became the character of the Chinese. Even in modern companies of Taiwan, the researches show that the Confucian work ethic prefers to respect hierarchy to attain harmony (Yeh and Xu, 2010).

\subsection{The Imperial Examination System}

The imperial examination system was another aspect to strengthen the authoritarian system. It was designed to select the administrative officials. This system was derived from Han Dynasty (202BC-220AD). Taixue, as the highest educational institution of the nation, was set up in Han dynasty. This was the original institution to train the professional public administrators. The emperor selected the officials through the imperial exam. Later, the examination systems got comprehensive development. The imperial examination system matured in Tang Dynasty (618-907AD) and being aborted in 1905.

The Imperial Examination System is an important feature of the traditional China. From Qin-Han to late Qing Dynasty, the imperial examination has developed into a comprehensive social structure (He Huaihong, 1998). It has profound influences to the education, politics, culture and ideology and even nature science.

In the education field, the imperial examination system showed the ideology and preferences of ruling class. Confucian theory is the basic knowledge that anyone who wants to pass the 
exam should grasp. Confucian theory's dominant position derived from Han Dynasty. One of the most important reforms in Han Dynasty is that, Emperor Liu Che adopted the scholar Dong's suggestion to abort the other thoughts and only respect Confucianism in the country. After that, the imperial examination policy was applied in the whole country. Only Confucian theory was the content of the examination. The other knowledge, such as science and technology, was omitted. That is one reason why nature science and new technology lay behind the West in contemporary history. The examination-oriented education system constrained the freedom of thoughts and indoctrinated the Confucian theory in people's mind.

From another perspective, the imperial examination offers an equal opportunity for the grass root to participate in the authoritarian regime. The researches show that $44 \%$ winners of the examination come from rural places, that is a very high proportion and even better than the situation in modern Western counties (He Huaihong, 1998). Therefore, imperial examination has a special role to realize political equality in the feudal society. However, such opportunity was controlled by the emperor. The examination would give the grass root a hope in surface. Its main objective is to maintain authoritarian ruling.

\subsection{Rewards and Punishment}

The history is not always peaceful. The struggles around the supremacy power never stop. The nobles, military generals, even the local authorities may eager to seek the supremacy dominance over the country. The details of the struggle would also be part of the research for historical institutionalism. As North claimed, once the petty affairs dominate the result, it would lead the history into a specific path (North, 1981). Limited by the length of article, I would not discuss the details here.

From the macro scope, we can find rewards and punishment play an important role during the process of strengthening the authoritarian power. Once the authoritarian power dominates the country, it would use the state apparatus to reward the obedience behavior and punish the unorthodoxy ideology and behaviors. Through the movements, such as Burning the books, burying the Confucian scholars, and Literacy persecution, the unorthodoxy thoughts were diminished. In the name of law, the complex merit systems and supervision systems were established in the whole country. What's more, with the expanding of emperor's power, the control over officials and the public are strengthened. For example, in Ming Dynasty, the secret spy agents, such as Dong Chang and Xi Chang, were established. Their main job was to inspect the officials and the citizens' speech and behavior. They could arrest the people without formal procedure.

The rewards and punishment have special meaning to strengthen the authoritarian regime. It increases the cost for changing. In the ideology field, it gives signals to the citizen and scholars to pay more attention to their speech. When it lasts long, the habit and informal institutions would be established in the whole society. Hence, the whole society would be under the control of dictatorship. 


\section{The Authoritarian Institutions and Chinese Culture}

The above is the basic framework of how the authoritarian institutions are strengthened. The Confucianism plays the role of political socialization, it indoctrinates the authoritarian thoughts and values into people's daily life; the imperial examination plays a role of political recruitment, which select the elites from the lower class to strengthen the authoritarian ruling; the reward and punishment is a mechanism to ensure the current institutions running according to the designed strategy; the government system represents the result of the political struggle. We can find the model in many countries on how to strengthen the ruling, for example, Hitler's Fascism in Germany. Culture and specific thoughts cooperate with other factors to strengthen the ruling. In the history of some European countries, such as UK and France, there is also an intention to develop into authoritarian regime in the history. But this emerging intention was diminished soon. But the situation in China is different. In some extend, the traditional Chinese culture delayed the democratization process.

My hypothesis is that the longer the dominate institution exists, the more difficult to replace it. That is the content of path dependence theory. But not all thoughts would be developed into dominate institutions. The dominate institutions mean those institutions adopted by the ruler in the history. For example, the free-market sprit in USA can be seen as dominate institution. The authoritarianism keeps dominate place and being accepted by the different level of society in China. Time is a key variable in the analysis. During the two thousands years, the authoritarian regime has been strengthened again and again. Gradually, it becomes a culture to be accepted by the public.

In fact, the discussion about the authoritarian regime and the mass culture reflects the relation of institution and culture. How is the culture formed? In this paper, I take the forming of culture as a gradually process. The culture was constructed by the institutions. That is a different analytical method from the cultural theory. For example, Almond and Verba (1963) analyze the political culture from the people's attitudes towards the role of self in the system. This method got many critiques later (see Street, 1994). Culture is a very broad concept which leads to the various analytical dimensions. In this paper, culture is a byproduct of authoritarian regime at the beginning, but at the final stage of feudal society, culture becomes the barrier of new thoughts.

The constructing of culture is an incremental process. In this paper, we find a comprehensive institutional setting at the original point of the authoritarian regime. It includes the military measures, economic measures, political measures, cultural measures and so forth. That is a systematic institutional setting. In the following dynasties, the intended and unintended measures strengthened the authoritarian regime. The culture reflects the result of the institutional transition. Zhan (1998) summarizes the influences of authoritarianism to the traditional culture in four points: the first is emphasizing the collectivism, personal willing should obey the group's requirements; the second point is Confucianism dominates the mainstream value, the other thoughts were forbidden; the third one is patriarchal system and the hierarchical views; the fourth point is conservative and no competition spirit. Compared with the western culture, the spirit of democracy and rationality are absent in Chinese culture 
(Liang, 2006). Likewise the definition of culture, this discourse is also disputable. But I think Liang wants to give out an over-all impression of the traditional Chinese culture from the comparative perspective.

If we analyze this issue from behaviorism's perspective, we would find another process of how the culture is formed. Some attitudes dominate the Chinese people's political value, for example, the obedience to government, authority, family and elder. In the social relations, ritual or politeness addressed. We can find answers from the authoritarian institutions. The authoritarianism would restrain the people's behavior. When such restriction continued over time, it would construct the people's habit. Such a habit would be transferred from generation to generation, and also advocated by the mainstream ideology. Finally it would become the national culture. This is the basic process of institution transferring into culture. As I analyzed above, the authoritarian culture also need support from other sectors. In China, the Confucian theory plays not only a role of philosophy, but also a political apparatus. The other sectors, such as the imperial examination system, the rewards and punishments have accelerated the socialization of authoritarianism into a secular culture. Therefore, we can see another kind of "to govern by doing nothing". The society runs automatically under the hierarchical control: father govern the family, the elder of the clan governs the village. Such a control is 360 degree from the daily behavior to inner world of the people in the local community. That is the way of how the authoritarian regimes permeated into people's daily life.

Another point is the relationship between time and institution. For many reasons, the authoritarian regime was developed comprehensively in China two thousand years ago. That is a miracle in that economic and cultural context (Gernet, 1995). As I discussed at the beginning of this paper, there is an increasing returns and path dependence in the institutions. When it lasts long, the comprehensive self-strengthen mechanism would be developed. In China, we can find the influence of authoritarianism from every aspects of the social life. Therefore, we may find that authoritarianism is an important feature of Chinese culture. Under the domination of this culture, people become conservative and arrogant. They obey the old institutions and no incentive to change. That is one principle of the authoritarian institution. Any attempts to change were forbidden. Inside the regime, they took them own as the central empire and enjoy the advanced culture. They took the close-door policy and don't want to absorb knowledge from the outside. In essence, these actions aim to strengthen and protect the authoritarian ruling. There is no chance for the democratic thoughts to spread in China until the New Culture Movement (mid 1910s and 1920s). Under such situation, the assimilation of mainstream political culture would be strengthened with time. The longer the institutions exist, the more difficult to change it. This conclusion supports Thelen's statement that even when policy makers set out to redesign institutions, they are constrained in what they can conceive of by these embedded, cultural constraints (Thelen, 1999).

From another dimension, the authoritarianism arouses the people' ambitious to control the others. The authoritarianism sets a hierarchical relationship in the society. The Confucian culture helps to strengthen the obedience of the social order. In the family, village and different level of the society, we can find the mechanism of maintaining the hierarchy ruling. The obedience to this order becomes moral virtue and behavior principle. Therefore, the strict 
hierarchical control was set up from the family to the whole country. Women become sacrifices of the culture. At the end of the feudal society, some abnormal values were add to women, for example, foot-binding and Zhen Jie Pai Fang (a stone arch erected by the government in honor of a chaste woman widowed at a young age). In fact, besides women, the other disadvantage groups, such as the junior generation, also have to obey the strict control from morality to behavior without any conditions.

The influence of the authoritarian culture is profound. When the authoritarian regime developed into the dominate institution in the society, it would be difficult for the grassroots to express their idea and get benefit from the upper class. Therefore, a special culture has been developed. Guan Xi plays an important role as the informal institution. Adaptability is the feature of the informal culture. With the special social network, one can realize his dream by avoiding conflicts with the authoritarian arrangement. To some extents, the Guan xi culture also helps to keep the authoritarian arrangement stable. The other aspects of the influences can be found everywhere. Limited by the length, I would not illustrate them here. But the core idea is clear. The complex institutions have the self-strengthen mechanism. The longer it exists, the more difficult to change it.

\section{Discussions and Conclusion}

As I state at the beginning of the paper, culture is a vague concept in political science. The topic of this paper is also a controversial issue. Some Chinese scholars would not agree with the proposition that there is no democracy in Chinese traditional culture. They would put forward a lot of examples about the advantages of Confucianism. Especially recent researches on the economic success of East Asia, some scholars attribute the reasons to the Confucianism (IP, 2009; Romar, 2008). Some scholars also deny the proposition that Confucian culture blocks democratization through the example of the Republic of Korea and Taiwan (Friedman, 1998). I do not deny this point. There is no clear causal relationship between the political culture and democracy (Street, 1998). However, the democratization is a complex process. The East Asian democratic countries have different history with the mainland China. The Confucianism in these countries was changed with the context. For example, the colonial history and education influenced the democratization. China has a different history with these countries. Anyway, no one could not deny the fact that the authoritarian regime has been kept as a dominate institution for two thousand years. This is the foundation of my proposition.

In this paper, I set the authoritarian regime an institution. It is a general idea. The authoritarian institution would include many aspects of the social life. In order to give the readers a clear impression, I give out a fourfold framework to analyze the authoritarian regime. That is a simplified model. These four aspects are the most important aspects for us to understand how the authoritarianism was strengthened. The authoritarianism is a political regime firstly. It would be represented in the government structure. In the special context of China, the Confucian culture could not be neglected, which influence the history greatly. Meanwhile, the imperial examination system supports the authoritarianism by selecting the intelligent resources and refreshing the elite groups. As we know, any institutions could not 
be implemented without man. The reward and punishment mechanism guarantees the authoritarianism to keep as orthodox ideology. These measures are important for constructing the authoritarian regime. This is a simple framework of analyzing the authoritarian regime. Each aspect has a long history. The details of the learning process are not mentioned here. We just show the framework of how to strengthen the authoritarian regime. The further analyses need to dig into details of each aspect and show us the learning process and conflicts between the institutions. Furthermore, power asymmetries and struggles is another dimension of institutional transition and development. It also requires us to discover the details from the historical affairs. I did not mention the details in this paper. However, the framework of historical institutional analysis is clear. It would give insights to those who are interested in this topic.

The contribution of this article is to explore the reasons of why the democratization process is difficult in China from historical institutionalism perspective. The origin of authoritarian regime has a vital position in this analysis. It describes the starting point of path dependence. However, how to incorporate the two thousand years history in the historical institutionalism analysis framework is a big challenge. This article explores the measures from bureaucracy system, Confucian theory, the imperial examination, rewards and punishments four aspects. Through such a framework, the authoritarian regime was strengthened. Especially the Confucian theory plays very important role in the socialization process of the authoritarian institutions. The four aspects cooperate with each other. The authoritarian institutions permeated into the traditional culture. The traditional culture was also adjusted to fit in with the authoritarian regime. As the results, the complex authoritarian structure has been constructed. The authoritarian regime and traditional culture were combined perfectly. In this sense, the authoritarian regime is socialized and showed in people's political attitude, cognition and daily behavior. It would help us to understand the democratic situation in China and its future development.

\section{References:}

Almond, Gabriel A. and G. Bingham Powell, Jr. 1978. Comparative politics: system, process and policy. Boston: Little Brown and Company.

Almond, G.A. and Verba, S. 1963. The civic culture: political attitudes and democracy in five nations. Princeton, NJ: Princeton University Press.

Andrew Nathan, et al. 1997. China's transition. New York: Columbia University.

Barrington Moore, JR. 1966. Social Origins of dictatorship and democracy. Boston: Beacon Press.

Creel, H. G. 1964. The beginnings of Bureaucracy in China: the origin of the Hsien, Journal of Asian Studies, 23(2):155-83.

Edward Freidman. 1999. Does China have the cultural preconditions for Democracy? Philosophy East and West, 49(3): 346-359. 
Fei Xiaotong. 1998. Rural China. Beijing: Peking University Press. ( in Chinese ) 费孝通. 乡村中国. 北京: 北京大学出版社, 1998.

Friedman, Edward. 1998. Chinese Culture and democracy. Journal of Democracy, 9(3):170-172.

Friedman, Edwards. 1999. Review: does China have the cultural precondition for democracy? Philosophy east and west, 49(3): 346-359.

Gallagher, Mary E. 2002. Reform and openness: why China's economic reforms have delayed democracy. World politics, 54(3): 338-372.

Gernet, Jacques. 1995. The social history of China. Translated by Geng sheng. Nanjing: Jiang Su Ren Min Press. (in Chinese ) 谢和耐（著）耿昇（译）.中国社会史. 南京: 江苏人民出 版社。

Hall, Peter and Taylor, Rosemary C.R. 1996. Political science and the three new institutionalisms. Political Studies, XLIV: 936-957.

Huntington, Samuel P. 1988. Political order in the changing society. Beijing: San Lian publishing House.

He Huaihong. 1998. The selection society and its end-A sociological explanation of Chinese history from Qin-Han to late-Qing period. Beijing: San Lian Press. (in Chinese ) 何怀宏. 选 举社会及其终结：秦汉至晚晴历史的一种社会学解释. 北京：三联书店，1998.

Held, David. Et al. 1999. Global transformation: politics, economics, and culture. Stanford Calif.: Stanford University Press.

Hood, Christopher. 1998. The Art of the state: culture, rhetoric and public management. Oxford: Clarendon Press.

IP, Pokeung. 2009. Is Confucianism good for business ethics in China? Journal of Business Ethics, 88: 463-476.

Kathleen Thelen and Sven Steinmo. 1992. Institutionalism in comparative politics. In Structuring Politics. Ed. By Sven Steinmo and Kathleen Thelen and Frank Longstreth. Cambridge University Press.

Lewis, John W. and Xue Litai. 2003. Social change and political reforms in China: meeting the changes of success. The China Quarterly, (176): 926-942.

Liang Shuming. 2006. The Eastern and Western culture and philosophy. Shanghai: shanghai publishing house. (in Chinese ). 梁漱溟. 东西文化与哲学. 上海：上海出版集团，2006.

Luo Weifeng. 2007. The globalization of human rights and the reflection of Chinese human rights. Master thesis of Xiamen University. ( in Chinese ) 罗伟峰. 人权全球化与中国人权 观的思考. 厦门大学, 硕士学位论文, 2007.

Ning Ke. 2009. the authoritarian centralism in Chinese feudal society. Journal of Literature, history and philosophy, 1: 89-100. ( in Chinese ) 宁可. 中国封建社会的专制主义中央集 
权. 文史哲, 2009, 1:89-100.

North, Douglass C. 1981. Structure and Change in Economic History. New York, W.W. Norton and Company.

Paul Pierson. 2000. The limits of design: explaining institutional origins and change. Governance: an international journal of policy and administration, 13(4): 475-499.

Paul Pierson. 2000. Increasing returns, path dependence and the study of politics. American Political Science Review, 94(2):251-267.

Romar, Edward J. 2008. Virtue is good business: Confucianism as a practical business ethics. Journal of Business Ethics, 38:119-131.

Sartori, Giovanni. 1987. The Theory of Democracy Revisited. Chatham, NJ: Chatham House.

Street, John. 1994. Political culture-from civic culture to mass culture. British Journal of political science, 24(1): 95-113.

Tan Sitong. 1994. On Benevolence. Dalian: Liaoning Renmin publishing House. (in Chinese ) 谭嗣同. 仁学. 大连: 辽宁人民出版社, 1994.

Thelen, Kathleen. 1999. Historical institutionalism in comparative politics. Annual Review of Political Science, 2: 369-404.

Wang Hanchang. 1984. Tentative discussion on the origin of feudal authoritarianism in China. Political Research, (1): 60-65. (in Chinese ) 王汉昌. 略论中国封建专制主义中央集权的 形成. 政治研究, 1984,1:60-65.

William M. Dugger, 1980. Power: an institutional framework of analysis. Journal of Economic Issues, 14(4):897-907.

Yeh Quex-Jen and Xu Xiaojun. 2010. The effects of Confucian work ethics on learning about science and Technology knowledge and morality. Journal of Business Ethics, 95:111-128.

Yong Wei. 1976. A methodological critiques of current studies on Chinese political culture. The Journal of Politics, 38(1): 114-140.

Zhan Jifa. 1998. Rethinking the influences of authoritarianism to the Chinese culture. The journal of Shanxi Normal University (Social Science edition), 25(1): 69-74. (in Chinese ) 战 继发. 专制主义对中国文化发展的影响反思. 山西师范大学学报（社会科学版），1998, 25(1): 69-74 